\title{
9.9. $\operatorname{mind}_{\text {IN }} \operatorname{dia}_{\text {I }}$
}

\section{The Value of Ethnography}

\author{
Tejaswini Ganti ${ }^{1}$ \\ New York University \\ tganti $[A T]$ nyu.edu
}

\begin{abstract}
:
As an anthropologist whose main methodological approach to the study of media industries is long-term ethnographic fieldwork, in my essay I want to highlight the importance of the issues of practice, social relations, and subjectivity to the study of mass media production as well as the utility of ethnography as a method. My approach to a large-scale market-driven media industry differs considerably from the legacy established by the Frankfurt School's "culture industry" approach to the analysis of mass media, whereby the political economic structures of production preclude discussions of subjectivity, agency, and meaning. I contend that in order to understand the complexities of media production, it is necessary to examine producers' sentiments and subjectivities in conjunction with questions of political economy. Regarding media producers as agents grounded in specific social, historical, and interpretive locations and their activity of production as comprising a domain of social practice complicates the discussion of commercial mass media production and takes it beyond simplistic assertions of the "bottom-line"-that somehow the pursuit of profit provides the limits of analysis.
\end{abstract}

Keywords: India, Film, Production, Ethnography, Research Methods

Imagine a media-making context where most contracts are oral, nothing is written down, nearly everyone is related, and no one knows exactly how much money a film has made. What sort of media industry is that? Actually, a very successful one-one that has been captivating and entertaining audiences throughout the globe for more than six decades. I am referring to the Hindi-language film industry located in Mumbai, an industry that is now more commonly referred to as "Bollywood" both within India and globally. Although aesthetically, culturally, and structurally distinct from Hollywood, the Hindi film industry is as prolific and powerful in its production and circulation of narratives and images; as globally ambitious in terms of seeking new markets; and as driven by commercial imperatives. As an anthropologist whose research site is the Hindi film industry and whose main methodological approach to the study of media industries is long-term ethnographic fieldwork, in this essay I want to highlight the utility of ethnography as a method that enables us to address questions of practice, social relations, and subjectivity-issues critical to understanding media industries, but mostly 
inaccessible from a conventional cultural industry approach. An ethnographic approach to media industries can help us to accomplish three important goals: to diversify the study of media industries; to take into account contestations over status and other forms of cultural and symbolic capital that characterize the "field" of media production; ${ }^{2}$ and to be able to critically examine discourses and quantitative data generated by media industries.

While it has become a truism that audiences and the practices of media consumption are diverse, scholars and lay people alike frequently assume that the processes of media production - mainly due to the technological properties of film and television - are somehow the same all over the world. An ethnographic approach to media production is important for understanding how differently media are produced, and for countering the ethnocentrism of much of the scholarship on media industries that is mainly based on the study of North American and Western European media institutions and corporate capitalism. Critically, the commercial nature of a media industry does not render its structure or organization transparent. For example, while the Hindi film industry is a commercially driven, blockbuster-oriented industry, its structures of financing and distribution, sites of power, organization of labor, and overall work culture are quite distinct from media industries located in the US. In contrast to Hollywood, the Hindi film industry is highly decentralized, has been financed primarily by entrepreneurial capital, organized along social and kin networks, and until the early 2000s was governed by oral rather than written contracts. Yet, even with its fragmented, decentralized, and informal nature, the Hindi film industry has been producing big-budget films that are as globally ubiquitous and commercially successful as those produced by integrated media conglomerates funded by corporate capital. Hence, within the field of media industry studies, we must expand our understanding of what an "industry" is and not presume certain organizational structures, division of labor, or financial arrangements from the outset. In fact, a productive avenue of inquiry would be to examine what structures, representations, and practices help to constitute a media industry as an "industry." For example, the Indian state granted "industry status" to filmmaking only in 1998, so one of the questions I explore in my research is the value and impact of that state recognition.

Ethnography grounds the study of media in a specific time and space and offers insights into the processes, possibilities, and constraints of media production that are not apparent from close readings of media texts or analysis of macro-level data about media institutions and commercial outcomes. A focus on the processes and practices of production allows us to look beyond the instances of "success" - those films or shows that do get completed and distributed in some manner-since many films or television shows do not progress beyond a conceptualization or pilot stage, and some are abandoned halfway. Such "failures" also add to our knowledge, offering productive insights and possibilities for theorizing about cinema and other media forms. ${ }^{3}$ Additionally, in contexts of financial secrecy and the willful absence of record keeping, ethnography offers insights into the production process that exhortations to simply "follow the money," i.e., to trace the broad contours of capital investment and ownership, could not achieve. ${ }^{4}$

Ethnography, however, is not just about interviewing people, but is centrally about paying attention to what Malinowski referred to as the "imponderabilia of everyday life," which is best achieved through long-term, sustained participant-observation. ${ }^{5}$ Spending time observing the daily life at the sites of media production provides an important contextual frame with which to understand media producers' self-representations and discourses about their practice. Paying attention to what people do in addition to what they say illuminates both norms and 
expectations of what constitutes appropriate or acceptable practice. A short-term or "parachuting" approach to research can make one miss or ignore important features of the production culture of a media industry because they may initially seem irrelevant to the "real work" of production. For example, throughout my fieldwork over the last two decades, I have consistently observed Hindi filmmakers lamenting the quality of filmmaking, bemoaning the lack of discipline and professionalism among their peers, and presenting themselves in the forefront of trying to organize and professionalize the industry. Rather than dismissing such attitudes as trivial or superfluous, I chose to examine what sort of work they were doing as these attitudes constituted such a significant part of the everyday life of film production in Mumbai. I realized that these sentiments and discourses operate as a form of "boundary-work," the industry's ideological efforts to define legitimate membership and practice. ${ }^{6}$ In a fragmented, decentralized industry marked by an abundance of producers, high rates of commercial failure, and historically high costs of capital, distinctions posited between genuine and illegitimate filmmakers have been significant for the process of raising finance. Thus, boundary-work is a discursive strategy that has significant material implications within the Hindi film industry. ${ }^{7}$ What sorts of formal and informal boundary-work practices exist in other media industries and what role do they play in shaping access to various forms of capital and resources?

An ethnographic approach to media production also enables us to incorporate questions of subjectivity and social relations into the analysis of mainstream mass media production. Studies of large-scale, commercially oriented media industries have neglected issues of individual subjectivity and social relations among cultural producers-a longstanding legacy of the Frankfurt School's "culture industry" approach to the analysis of mass media. ${ }^{8}$ Analyses of subjectivity -in terms of affect, perceptions, thoughts, sentiments, and desires that constitute the basis of agency - and the complex production of meaning have more often been the concern of scholars studying media audiences, or indigenous, oppositional, minority media practitioners. In order to understand the complexities of media production, it is necessary to examine producers' sentiments and subjectivities in conjunction with questions of political economy. For example, I realized during my research that Hindi filmmakers were extremely concerned with issues of prestige, status, and cultural legitimacy. These concerns manifested most strongly in their highly disdainful attitudes toward the majority of their audiences in India, so much so that once certain structural changes around distribution and exhibition came into place, the driving commercial logic of the Hindi film industry for the first decade of the millennium was characterized by an inverse relationship between the numbers of viewers and the amount of revenue; in other words, rather than trying to expand their market, filmmakers were trying to make more money from fewer people. ${ }^{9}$

Regarding media industries as populated by agents grounded in specific social, historical, and interpretive locations reminds us to be wary of reproducing industry discourses about success and other assessments of popularity. As scholars, we need to be cautious with how we deal with the barrage of statistics and aggregate figures generated by media industries. Numbers should not be taken as objective realities, but as postulates put forward to make certain assertions or claims about our social world. ${ }^{10}$ For example, media scholars have long pointed out that audiences for large-scale culture industries such as television are literally unknowable. ${ }^{11}$ I would argue that the same conclusions could be applied to film audiences as well. Box-office receipts merely quantify the act of purchasing a ticket, which at the most measures awareness and interest in a film, but not the more complex processes of reception. 
Box-office data does not yield information about viewers' intentions, perceptions, experiences, likes, or dislikes; in fact, displeasure with a film once it has been viewed in a theater can never really be quantified, since the action of purchasing a ticket gets registered and interpreted as audience approval. While box-office outcome at best can be understood as an index of a commercial transaction, media producers frequently interpret it as an indexical expression of social identity, subjectivity, and affect. Industry categories, however, should not be our analytical categories; instead, we should ask, what stories are media industries trying to tell, or what claims are media producers making, through their use of quantitative data? Otherwise, we fall into the trap of replicating the discourses of the very industries that we are attempting to analyze. Thus, one challenge that we face as scholars of media industries is to not jump too quickly to extrapolate from media consumption to subjectivity or vice versa. Furthermore, how do we theorize about affect and engagement with visual media that does not replicate or mirror what media producers are asserting?

Viewing mainstream filmmakers as complex beings who seek and make meaning through their work helps to "break up the 'massness' of the media,"12 and reminds us that for-profit mediamaking are neither simple acts of conscious manipulation nor unthinking, mechanical ones, but rather social practices undertaken by complex subjects with diverse interests and motivations.

${ }^{1}$ A visual anthropologist specializing in South Asia, Tejaswini Ganti's research interests include Indian cinema, anthropology of media, production cultures, visual culture, cultural policy, nationalism, neoliberalism, capitalism, ideologies of development, and theories of globalization. She has been conducting ethnographic research about the social world and filmmaking practices of the Hindi film industry since 1996 and is the author of Producing Bollywood: Inside the Contemporary Hindi Film Industry (Duke University Press, 2012) and Bollywood: A Guidebook to Popular Hindi Cinema (Routledge, 2004; 2nd ed., 2013).

2 Pierre Bourdieu, The Field of Cultural Production (New York: Columbia University Press, 1993).

3 Tejaswini Ganti, “And Yet My Heart Is Still Indian: The Bombay Film Industry and the (H)Indianization of Hollywood," in Media Worlds: Anthropology on New Terrain, ed. Faye D. Ginsburg et al. (Berkeley: University of California Press, 2002), 283.

4 Tejaswini Ganti, Producing Bollywood: Inside the Contemporary Hindi Film Industry (Durham: Duke University Press, 2012), 22.

5 Bronislaw Malinowski, Argonauts of the Western Pacific (Prospect Heights: Waveland Press, 1984), 20.

6 Thomas Gieryn, "Boundary-Work and the Demarcation of Science from Non-Science: Strains and Interests in Professional Ideologies of Scientists," American Sociological Review 48, no. 6 (1983): 781.

7 Tejaswini Ganti, "Sentiments of Disdain and Practices of Distinction: Boundary-Work, Subjectivity, and Value in the Hindi Film Industry," The Anthropological Quarterly 85, no. 1 (2012): 7.

8 Mark Banks, The Politics of Cultural Work (New York: Palgrave MacMillan, 2007), 28.

9 Tejaswini Ganti, Producing Bollywood: Inside the Contemporary Hindi Film Industry

(Durham: Duke University Press, 2012), 346.

${ }_{10}$ Mary Poovey, A History of the Modern Fact (Chicago: University of Chicago, 1998), xii. 
11 Ien Ang, Desperately Seeking the Audience (London: Routledge, 1991); John Hartley, "Invisible Fictions: Television Audiences, Paeodocracy, Pleasure," Textual Practice 1, no. 2 (1987): 121-38.

12 Faye Ginsburg, "Culture/Media: A (Mild) Polemic," Anthropology Today 10, no. 2 (1994): 12.

\section{Bibliography}

Ang, Ien. Desperately Seeking the Audience. London: Routledge, 1991.

Banks, Mark. The Politics of Cultural Work. New York: Palgrave MacMillan, 2007.

Bourdieu, Pierre. The Field of Cultural Production. New York: Columbia University Press, 1993.

Ganti, Tejaswini. "Sentiments of Disdain and Practices of Distinction: Boundary-Work, Subjectivity, and Value in the Hindi Film Industry." The Anthropological Quarterly 85, no. 1 (2012): 5-43.

Ganti, Tejaswini. Producing Bollywood: Inside the Contemporary Hindi Film Industry. Durham: Duke University Press, 2012.

Ganti, Tejaswini. “And Yet My Heart Is Still Indian: The Bombay Film Industry and the (H)Indianization of Hollywood." In Media Worlds: Anthropology on New Terrain, edited by Faye D. Ginsburg, Lila Abu-Lughod, and Brian Larkin, 281-300. Berkeley: University of California Press, 2002.

Gieryn, Thomas. "Boundary-Work and the Demarcation of Science from Non-Science: Strains and Interests in Professional Ideologies of Scientists." American Sociological Review 48, no. 6 (1983): 781-95.

Ginsburg, Faye. “Culture/Media: A (Mild) Polemic.” Anthropology Today 10, no. 2 (1994): 5-15.

Hartley, John. “Invisible Fictions: Television Audiences, Paeodocracy, Pleasure.” Textual Practice 1, no. 2 (1987): 121-38.

Malinowski, Bronislaw. Argonauts of the Western Pacific. Prospect Heights: Waveland Press, 1984. Poovey, Mary. A History of the Modern Fact. Chicago: University of Chicago, 1998.

\section{$(\mathrm{Cc}) \mathrm{BY}-\mathrm{NC}-\mathrm{ND}$}

Copyright (C) 2014 (Tejaswini Ganti). Media Industries is an open-access, peer-reviewed, online academic journal. As such, we aim to participate in the open exchange of information. This work is licensed under a Creative Commons Attribution Noncommercial No Derivatives (by-nc-nd) License. Under this license, this work is available for sharing and noncommercial distribution provided the appropriate attribution is given. 